\title{
The Effect of Research \& Development Investments on New Firm Entry
}

\author{
Panagiotis Kotsios ${ }^{1}$, Aglaia Gkampoura ${ }^{1} \&$ Vaios Kotsios ${ }^{2}$ \\ ${ }^{1}$ Technological Institute of Thessaly, Larissa, Greece \\ ${ }^{2}$ National Technical University of Athens, Patission 42, Athens, 10682, Greece \\ Correspondence: Dr. Panagiotis Kotsios, Technological Institute of Thessaly, Larissa, Greece. Tel: 30-698-385-2592. \\ E-mail: panagiotiskotsios@gmail.com
}

Received: December 10, 2014

Accepted: December 30, $2014 \quad$ Online Published: January 6, 2015

doi:10.5430/rwe.v6n1p112

URL: http://dx.doi.org/10.5430/rwe.v6n1p112

\begin{abstract}
The entry of new competitors operates as a balancing force against high levels of industrial concentration and the abuse of dominant position by firms with large market shares. This paper's goal is to examine theoretically the impact of Research \& Development investments on new firm entry. While dominant economic theory supports that large R\&D investments are a prerequisite for technological change and economic growth, so that large incumbent firms are considered to have an advantage against new, typically smaller firms, theoretical and empirical research has shown that this may not be the case. Small firms' contribution in innovation and economic development is far greater than expected.
\end{abstract}

Keywords: R\&D, entry, barriers, competition

\section{Introduction}

This paper's goal is to examine the effect of Research \& Development investments on new firm entry. In order to achieve this goal entry, firstly barriers to entry and R\&D will be defined and explained. The effect of $R \& D$ investments on new firm entry will be evaluated by presenting the various arguments for and against their role as an entry barrier. The conclusions of the study will be drawn in the last part.

\section{Entry \& Barriers to Entry}

The entry of new competitors relates with the appearance of a new producer in a market (OECD, 2005). Entry can take many forms, such as foreign direct investment (FDI), trade licenses, joint ventures, strategic alliances, acquisitions, direct exports or greenfield investments in new industrial facilities. The entry of new competitors operates as a balancing force against high levels of industrial concentration and the abuse of dominant position by firms with large market shares. Entry increases supply, lowers prices, intensifies innovation and restores equilibrium to the markets that don't operate in a socially desirable manner.

The ease of entry is adjusted according to the number and height of barriers to entry. Various definitions of barriers to entry have been proposed in the industrial organization literature, as the ones by Bain (1956), Stigler (1968), Ferguson (1974), Caves \& Porter (1977), Fisher (1979), VonWeizsacker (1980), Demsetz (1982), Baumol \& Willig (1981), Gilbert (1989), Geroski et al (1990), Carlton \& Perloff (1994), Church \& Ware (2000), McAfee et al (2004) and the OECD (2005).

The definition adopted in the current study is the following: a barrier to entry is defined as anything that restricts competition in a sector, when more competition would be socially beneficial. It is based on Fisher's (1979) definition, with a small variation: the phrase "anything that restricts entry" in Fisher's definition was replaced by the phrase "anything that restricts competition". This change was necessary in order to cover cases of mobility barriers from one intersectoral effectiveness group to the other. This definition can include a large number of possible barriers to entry, covers intra- and extra-sector mobility situations and clearly points out the aim of the whole analysis, which is social welfare enhancement.

In regard to the categorization of barriers to entry, the most practical separation proposed in the literature was the one made by Geroski et al (1990). They distinguish between structural and strategic barriers to entry. Structural barriers arise from the exogenous demand, cost and technology conditions of an industry and are the same for all firms, new or incumbent, while strategic barriers are created from the actions and strategic choices of incumbent firms. Although this separation is far from perfect, as many barriers fall in both categories, it is a good starting point for a thorough analysis of the barrier to entry theory. Examples of structural barriers are economies of scale and capital 
costs, while examples of strategic barriers are limit pricing and collusion. $R \& D$ is considered as a structural barrier to entry, however it also has a strategic side, as incumbent firms may use R\&D strategically it in order to impede new competitors.

\section{Research \& Development}

Research and Development (R\&D) is an activity met in many modern organizations and especially those that operate in high-tech sectors. Its aim is to produce technological change and innovation. Technological change and innovation refer to the development and introduction of new products, services, materials, production methods, supply sources, technical procedures and organizational forms. R\&D offers competitive advantages to successful innovators and improves social welfare. On the social level, new technology has a positive impact on the efficient use of available resources, on economic growth and living standards, while on the industry level it has an impact on production, product quality, employment, wages and profits. Consequently, the extent to which industries develop new ideas and promote new products and services, affects not only private firms, but society as a whole. Innovation, however, like all other economic activities, is not free of charge. It absorbs economic resources in the form of R\&D expenditures. $R \& D$ expenditures are the money spent on creative work, undertaken on a regular basis, in order to increase the stock of knowledge used to devise new or to improve existing applications. R\&D expenditures take the form of investments in building laboratories, occupying specialized personnel, experimenting and establishing cooperation networks with organizations, universities, research centers, private firms and individuals. R\&D is a process that involves many different stages. Among economists there is a disagreement about the title and the number of stages. The oldest and most well-known classification is that of Schumpeter (1942) to invention, innovation and diffusion. Modern economists, such as George et al (1992) and Lipzcynski \& Wilson (2001), have suggested a more detailed classification. They separate $\mathrm{R} \& \mathrm{D}$ in basic research (evolution of ideas and inventive activity for scientific reasons), applied research (research aiming to determine commercialization potential of a new application), development (organizing production facilities), commercial production and innovation (full-scale production, promotion and distribution) and diffusion (spread of the new idea to the market). Nevertheless it would be wrong to interpret these stages as stages of a linear process. Each stage is characterized by different parameters, the results of which affect the parameters of the other stages. For example, inventions improve drastically after they are put into widespread use.

\section{The Effect of R\&D Investments on New Firm Entry}

The evaluation of the impact that R\&D has on new firm entry, will be carrier out by outlining the arguments that have been put forward for and against its role as an entry barrier.

\subsection{R\&D Affects Entry}

Several of the arguments in favor of the view that $R \& D$ is a barrier to entry, have their theoretical basis on the classic text by Joseph Schumpeter, Capitalism, Socialism and Democracy (1942) and the work of economists who have followed the same line of thought, such as Galbraith (1956) and Chandler (1977). Schumpeter saw technological change as an integral component of capitalist markets which disturbs the equilibrium in industrial competition and creates destabilizing short-term market trends. The results of this disruptive force is the introduction of new, more efficient, goods and services and the replacement of established firms that are tied in older, less efficient technologies, with new, more efficient ones. He referred to this system as "creative destruction". He argued then that the optimal market structure is not perfect competition, but a form of monopoly that includes a degree of potential competition from new products or processes. These new products may, at any time, replace the monopolist's current product or production process. The monopolist, in order to defend his market share, instead of being based on the price mechanism, he should remain vigilant for the new technologies that will determine future demand.

Schumpeter identified the large monopolistic company as a key driver in the process of technological change. Characteristically he mentioned (1942, p. 106): "What we have to accept is that (large company) has become the most powerful engine of progress." He considered market dominance as a prerequisite for the acceptance of risk associated with innovation, and he argued that only large firms could meet this criterion successfully (Audretsch, 2004). As Schumpeter mentions elsewhere in his text (1942, p. 101): "for there are advantages which, though not strictly unattainable on the competitive level of enterprise, are as a matter of fact secured only on the monopoly

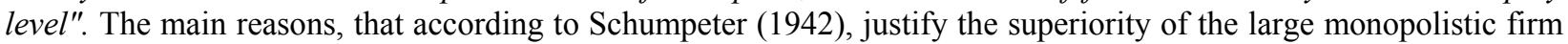
over small competitors, are the availability of financial resources and the security offered by the large market share against the risk of failure. Some other causes can be found in Galbraith (1956), and have to do with the ability to share the risk of failure by taking on multiple projects, the ability to achieve economies of scale in R\&D and the ability to use distribution and marketing advantages in order to penetrate markets more and accelerate R\&D returns on investment. Other arguments in favor of the large firm were mentioned by Yamey (1972) [15], and relate with its ability to secure superior factors of production for research and its ability to take advantage of a safe competitive environment in order to focus on R\&D projects. Consequently, according to the Schumpeterian hypothesis, small 
and medium size scale entry are destined to fail, since small and medium-sized companies will never be able to survive in the long term. The only chance of successful entry and seize of market share could come either from new firms that invest heavily in R\&D, or from large firms that diversify from other sectors. Examples of empirical studies that support the Schumpeterian hypothesis are those of Freeman (1974) and Alexander et al. (1995).

Nevertheless, the arguments that $R \& D$ affects entry do not stop here. As mentioned earlier, the most fundamental barrier to R\&D are capital requirements. Incumbent firms may use a part of their profits in order to fund their research activities. New firms on the other hand, should, in most cases, turn to the capital market. While turning to the capital market, the new firm will face a number of disadvantages: difficulty in securing loans, as new firms cannot prove their ability to repay them and difficulty in convincing financial institutions to fund R\&D projects, as $R \& D$ projects involve a high risk of failure and most of these investments constitute sunk costs. Other problems arise from the high interest rates and the long repayment period needed, in most cases, in order to diffuse an innovation and start gaining economic returns from it. All the above affect entry levels and entry modes. A first case is that entry will not occur, since a new firm will not succeed in obtaining the necessary finance. The other case is that entry will take place, but with many disadvantages for the incoming firm. Examples of these disadvantages are the limited amount of funds, the inability to employ highly qualified personnel, the lack of equipment, lack of facilities, lack of communication infrastructure etc. Another case is that the new firm will take on a short R\&D project, satisfying thus the desire of investors to avoid high risk and earn fast economic returns. The last case is that R\&D will be carried out by using solely own funds, but this can be done from a limited number of firms.

Another advantage of incumbent firms relates with economies of scale in R\&D (Galbraith, 1956; Comanor, 1967; Scherer, 1991). Economies of scale in R\&D are mainly due to reduced costs and increased profitability resulting from better use of expertise staff, laboratories, distribution and promotion networks. Economies of scope in R\&D also play an important role. As pointed out by Galbraith (1967), the uncertain nature of R\&D means that a larger portfolio of research programs has a safer return than a smaller one. The reason is that technological progress that takes place in one project can also be used in different projects. A small new firm, on the other hand, faces high risk, as it must concentrate all its efforts in developing a single innovative idea, the success or failure of which will determine its survival (George et al, 1992).

Another aspect that has to be mentioned, relates to the cost advantages, of established firms, arising from R\&D. These come mainly through learning curves, cooperation networks and patents. Learning curves can lead to significant reductions in R\&D costs and faster diffusion of innovations to the market. Incumbent firms that have considerable experience in $\mathrm{R} \& \mathrm{D}$, are in a advantageous position, in relation to new firms that are the start of their learning curve (Geroski, 1991). Cooperation networks operate in a similar way, as incumbent firms have already organized their networks. These networks can be either with rivals, or with firms in other stages of production process (e.g. suppliers and distributors). Networks can contribute significantly in R\&D through the exchange of information, expertise, materials, personnel and funds. The absence of such networks for new firms leads to an increase in their projects' duration and cost. Patents affect entry in connection with the all the above. They lead to advantages such as monopoly profits and exclusivity for a long period of time.

Moreover, because of the particularity of the R\&D issue, it is necessary to refer to organizational and administrative obstacles that may arise during the implementation of R\&D projects. These barriers can affect new firms seeking to conduct R\&D and create disadvantages against better organized, experienced firms in the industry. These range from lack of managerial experience in carrying out $R \& D$ projects, non-flexible organizational structures, lack of communication with the external environment, lack of communication from one organizational level to another, lack of incentives and awards for research, lack of connection of R\&D with the market, lack of staff training etc. Overcoming these obstacles requires flexible organizational structures and carefully designed networks of communication between different parts of the firm and between the firm and the market. New firms require a considerable amount of time to organize all these.

The last aspect of R\&D that can affect entry relates with the strategic behavior of incumbent firms. As observed by Lipczynski \& Wilson (2001) [based on the Freeman \& Soete (1997): "in an economic environment that most decision-making is characterized by uncertainty, it is unrealistic to assume that firms see policies as innovation effort as a means only for maximizing profits" (p. 239). Their argument is that R\&D may have strategic objectives, as obtaining market power, raising entry barriers and forcing the exit of competitors from the industry. This, according to Geroski (1991), occurs because the actual pre-innovation extent of market power of established firms, is likely to depend on barriers to entry, and barriers to entry will also protect the firm after the diffusion of the innovation. Another strategic choice related with R\&D is the "aggressive" R\&D strategy (as indicated by Lipczynski \& Wilson, 2001). This strategy consists of large investments in R\&D with a goal to take over the market through technological change. It involves a large degree of experimental research, securing patents, educating the market in the use of 
innovations and massive promotion of new products. A final policy option is the use of the compatibility standards, where old and new products are linked to each other and are made incompatible with other competing products.

\subsection{R\&D Does Not Affect Entry}

As presented in the previous part, the arguments for the view that R\&D affects entry are many. Most of them, however, can be neutralized if we consider the arguments of the opposite side, that R\&D is more a means and incentive to enter than an obstacle. The analysis of the arguments will begin with the arguments against the Schumpeterian hypothesis, will continue by highlighting the role of small firms and will be completed by explaining the entry options associated with R\&D.

Starting with Schumpeter's theory on the role of the large monopolistic firm in technological change, it is possible to observe a large number of arguments that support exactly the opposite view, that the large firm is at a disadvantageous position for creating innovations. A first argument concerns capital requirements. Monopolistic firms that invest heavily in R\&D, beyond the direct loss of earnings they suffer, they also face the risk of not winning anything from these investments. There is always the possibility that $R \& D$ will not bring any satisfactory results, or the results achieved will not commercially exploitable. There is also the possibility that the results of the research will have no great commercial value or a very long period may be needed until they yield positive economic returns. Also, there is always the risk of confidential information about an innovation to leak to competitors, who will exploit them for their own commercial purposes, making the innovative large firm unable to recoup the investments made. This could also occur, likewise, through the appropriation of research results by staff of the R\&D department, who wish to start their own personal firms. Two other disadvantages associated with the large monopolistic firm have to do with inertia and denial to change. Inertia and refusal to change occur when a large firm rests in the current profitability and market dominance and fails to identify major challenges arising from new technology (Lipczynski $\&$ Wilson, 2001). However, the design and development of new products is very often a critical factor in the survival of a business. Especially in industries where technology changes rapidly, firms must constantly revise their product and services line.

In relation to the above, two other major drawbacks of incumbent firms must be mentioned. The first is that these firms may have made large investments in existing technologies and production methods, so the conversion needed to produce a new product may be very expensive. This occurs especially when the conversion process involves replacing or discarding a large proportion of fixed capital (e.g. machinery). The second relates with the difficulty of organizing and managing a large organization. The managerial problems and challenges faced by a large monopolistic firm are surely bigger than a small firm that employs a limited number of employees. It could even be argued, contrary to the argument that large firms carry out R\&D projects in a safe environment, that the biggest challenges for these firms come from within the firm and not from the external environment. In relation to the above Blair (1972) concluded that in contrast to the great discoveries of the $19^{\text {th }}$ century, like steam power and railways, which encouraged the creation of large firms, the innovations of the $20^{\text {th }}$ century, such as electricity and plastic, reduced the minimum efficient scale in many industries, allowing a more competitive structure of the sectors.

As a consequence the economic theory about the role of small firms in technological change was developed. Empirical studies such as that of Jewkes et al (1969) stressed the importance of small firms in innovative activity. In their study for the period 1930-1950, the authors found that from the 61 major discoveries only 12 could be attributed in large firms, while 38 were due to the work of individuals and small firms (11 were not ranked in any category). Birch (1981) [25] found that small firms provide the basic engine of job creation in the U.S. In recent years there has been a large number of studies with similar findings (e.g. Geroski, 1994; Audretsch, 2004). These studies have identified a much wider range of businesses that contribute in innovative activity and revealed that small firms play an important role in the process of innovation and technological change.

A key reason that led to discovery of the role of small firms in innovation, was the use of innovation output as a measurement tool for technological change. As long as the basic tools for measuring innovation were limited to inputs in the innovative process, such as expenditures on formal R\&D, most innovative activities of small firms remained difficult to be detected by researchers (Audretsch, 2004). Investment in R\&D, however, reflects the economic resources devoted to technological change, but not the amount of technological change actually created. Kleinknecht (1987) argued that most measurements of R\&D includes the innovative activity carried out on the official R\&D budgets and special workshops, and not the informal R\&D that takes place in small firms. With the development of measures focusing on innovative output (patent applications and registrations), the vital contribution of small firms in innovative activity was revealed. Examples of empirical studies that highlight the role of small firms in innovation are those by Pavitt et al (1987), Feinman \& Fuentevilla (1976) and Edwards \& Gordon (1984).

Rothwell (1989) suggested that the factors that create advantages for small firms generally come from the difference in management structures between large and small firms. A small firm has a smaller and more flexible organizational 
structure, so the exchange of information can be done faster and more efficiently. Scherer (1991) argued that the bureaucratic organization of large firms is a major obstacle in undertaking R\&D projects. The decision to innovate must pass several layers of bureaucracy, where inertia leads to a bias against the risk associated with launching new research programs. In contrast, small firms' innovative activity may flourish in the absence of bureaucratic constraints (Link \& Bozeman, 1991 [32]), since the decision to innovate is taken by only a few people. This means better communication between employees and management, better interpersonal relationships and more enthusiasm. Another reason which gives advantages to small firms to conduct innovation activity is related, according to Scherer (1980), with the production by small firms of several small inventions, such as parts and materials. The sales opportunities for these small inventions are often too modest to interest large firms. Also, many small firms have benefited from hiring researchers who either did not withstand the strict organizational structures and constraints of large firms or did not agree with the system of rewards. Finally, it should be noted that small firms can bypass various disadvantages by establishing cooperation networks with other firms and organizations and through contacts with external sources of technical information such as research institutes and academic journals (George et al, 1992). A final aspect of innovation activity associated with the activities of small firms is the one that claims that patents, even though they are the most widespread measure of innovative output, they do not always capture all kinds of innovations. The reasons behind this fact is twofold: The first is that a patent reflects new technical knowledge but does not reflect whether this new knowledge has a positive economic value, and the second is that many innovations do not lead to patents, but their inventors prefer to diffuse them freely to the market, as they see that this way, the benefits are larger. Typical is the study conducted by Levin (1986) in R\&D managers of 130 U.S. industries, finding that, apart from the pharmaceutical industry, patents are not considered an effective protection method for innovations in research-dynamic industries.

Other arguments in favor of the view that R\&D is not a barrier to entry, relate with the strategic choices of new entrants. Some new firms will use completely new technology in order to win market share. But that is not the only strategic direction available. According to Lipczynski \& Wilson (2001), a new firm may follow a "defensive" strategy. This policy is used after a major new product or service appears in the market and it is intended to improve or differentiate it in order to win market share. It involves close monitoring of technological developments. Another option is the "imitative" policy. Unlike the defensive firm, imitators do not wish to produce a better product than those promoted by aggressive and defensive firms. Instead they are happy to produce a similar product, either by special permit or by taking advantage free knowledge. A third option is the "dependent" policy. This means the new firm acts as a satellite or subcontractor of defensive or aggressive firms in the industry. A final policy is the "traditional", which is found in areas not affected by technology. This is due to the nature of market demand: consumers either do not seek the frequent technical changes in the products or do not monitor market developments. The final choice of strategic direction will depend, to a large extent, on the type, size and growth of the market.

\section{Conclusions}

Even though traditional economic theory supports that large incumbent firms have an advantage against new, typically smaller firms, due to the large investments they make in $R \& D$, theoretical and empirical research has shown that this may not be the case. Small firms' contribution in innovation and economic development is far greater than expected. This fact on the one hand minimizes the impact of incumbents firms' R\&D investments on competition, and on the other highlights the need for state promotion of new firm entry. Governments that wish to see their economies grow, must combine competition policy aimed to reduce incumbent firms' structural and strategic barriers to entry, with financial and regulatory motives for new business start ups.

\section{References}

Alexander, D. L., Flynn, J., \& Linkins, L. (1995). Innovation Innovation, R\&D Productivity and global market share in the pharmaceutical industry. Review of Industrial Organisation, 10, 197-207. http://dx.doi.org/10.1007/BF01029676

Audretsch, D. (2004). Small firm innovation and competition. In M. Neumann and J. Weigand (Eds.), International handbook of competition (pp.88-108). Elgar, Cheltenham. http://dx.doi.org/10.4337/9781849806060

Bain, J. (1956). Barriers to new competition. Harvard University.

Birch, D. L. (1981). Who creates jobs? Public Interest, 65(1), 3-14.

Blair, J. (1972). Economic concentration. New York, Harcourt, Brace Jovanovich.

Caves, R., \& Porter, M. (1977). From entry barriers to mobility barriers: conjectural decisions and contrived deterrence to new competition. Quarterly Journal of Economics, 91(2), 247-261. http://dx.doi.org/10.2307/1885416 
Chandler, A. (1977). The visible hand: the managerial revolution in American business. Cambridge, MA, Harvard University Press.

Comanor, W. S. (1967). Market structure, product differentiation, and industrial research. Quarterly Journal of Economics, 81(4), 639-657. http://dx.doi.org/10.2307/1885583

Edwards, K. L., \& Gordon, T.J. (1984). Characterization of innovations introduced on the U.S. market in 1982. The Futures Group, prepared for the U.S. Small Business Administration.

Feinman, S., \& Fuentevilla, W. (1976). Indicators of international trends in technical innovation. Report to National Science Foundation by Gellman Research Associates.

Fisher, F. M. (1979). Diagnosing monopoly. Quarterly Review of Economics and Business, 19(2), 7-33.

Freeman, C. (1974). The Economics of Industrial Innovation. Harmondsworth, Penguin.

Freeman, C., \& Soete, L. (1997). The economics of industrial innovation ( $3^{\text {rd }}$ ed.). London, Pinter.

Galbraith, J. K. (1956). American capitalism: the concept of countervailing power. Boston, MA, Houghton Mifflin.

Galbraith, J. K. (1967). The new industrial estate. Boston, MA, Houghton Mifflin.

George, K. D., Joll, C., \& Lynk, E. L. (1992). Industrial organisation: competition, growth, and structural change $\left(4^{\text {th }}\right.$ ed). Routledge.

Geroski, P., Gilbert, R., \& Jacquemin, A. (1990). Barriers to entry and strategic competition. New York, Harwood Academic Publishers.

Geroski, P. (1991). Market dynamics and entry. Blackwell.

Geroski, P. (1994). Market structure, corporate performance and innovative activity. Oxford, Clarendon Press.

Jewkes, J., Sawers, D., \& Stillerman, R. (1969). The sources of invention. London, Macmillan.

Kleinknecht, A. (1987). Measuring R\&D in small firms: how much are we missing?. Journal of Industrial Economics, 36(2), 253-256. http://dx.doi.org/10.2307/2098417

Levin, R. C. (1986). A new look at the patent system. American Economic Review, 76(2), 199-202.

Link, A. N., \& Bozeman, B. (1991). Innovative behavior in small-sized firms. Small Business Economics, 3(3), 179-84. http://dx.doi.org/10.1007/BF00400023

Lipczynski, J., \& Wilson, J. (2001). Industrial organisation: an analysis of competing markets. Harlow, Financial Times Prentice Hall.

McAfee, R. P., Mialon, H., \& Williams, M. (2004). What is a barrier to entry?. American Economic Review, Papers and Proceedings, 94(2), 461-465. http://dx.doi.org/10.2139/ssrn.594601

Organisation for the Economic Cooperation and Development, (2005). Barriers to entry. Policy Roundtables, $\mathrm{DAF} / \mathrm{COMP}(2005) 42$.

Pavitt, K., Robson, M., \& Townsend, J. (1987). The size distribution of innovating firms in the U.K.: 1945-1983. Journal of Industrial Economics, 35(3), 291-316. http://dx.doi.org/10.2307/2098636

Rothwell, R. (1989). Small firms, innovation and industrial change. Small Business Economics, 1(1), 51-64. http://dx.doi.org/10.1007/BF00389916

Scherer, F. M. (1980). Industrial market structure and economic performance (2 $2^{\text {nd }}$ ed.). Chicago, IL, Rand McNally.

Scherer, F.M. (1991). Changing perspectives on the firm size problem. In Z. J. Acs and D. B. Audretsch (Eds.), Innovation and technological change: an international comparison (pp. 24-38). Ann Arbor, University of Michigan Press.

Schumpeter, J. (1942). Capitalism, socialism and democracy. New York, Harper.

Stigler, G. (1968). The organization of industry. Homewood, Ill Richard D. Irwin.

VonWeizsacker, C. (1980). A welfare analysis of barriers to entry. Bell Journal of Economics, 11(2), 399-420. http://dx.doi.org/10.2307/3003371

Yamey, B. S. (1972). Do monopoly and near monopoly matter? A survey of the empirical studies. In M. Peston and B. Correy (Eds.), Essays in Honour of Lord Robbins (pp. 294-308). London, Weidenfeld \& Nicolson. 